\title{
The Conventional Lies: An Almost Forgotten Concept
}

\author{
NICOLAE RÂMBU \\ Faculty of Philosophy, University 'Alexandru loan Cuza' lași, B-dul Carol I, 11 lasi, 700506 Romania \\ Email: nikolausrambu@yahoo.de
}

\begin{abstract}
The concept of conventional lie, first defined by Friedrich Nietzsche, should be used in the discourse of the cultural sciences. This is because the series of phenomena that it designates is usually mistakenly classified either in the category of stereotypes or in the one of prejudices. In this article, the thesis that conventional lies represent a specific element of culture as a 'software of the mind' is supported.
\end{abstract}

Keywords: intercultural communication, Friedrich Nietzsche, the immorality of morality

\section{PIA FRAUS}

All rational people agree that the truth represents one of the highest values. In one form or another, all civilizations have worshipped the truth and condemned the lie. But if we ask what truth is in the Socratic way, then even the greatest philosophers and theorists of civilizations would be put to the test. This is especially so if we refer to the truth in the moral sense. Friedrich Nietzsche's answer to the above question is significant for what he called a conventional lie: 'What, then, is truth? A mobile army of metaphors, metonyms, and anthropomorphisms - in short, a sum of human relations which have been enhanced, transposed, and embellished poetically and rhetorically, and which after long use seem firm, canonical, and obligatory to a people: truths are illusions about which one has forgotten that this is what they are' (Nietzsche 1982: 46-47). The society, says Friedrich Nietzsche, in order to exist, imposes on all of its members 'the obligation to lie according to a fixed convention, to lie herd-like in a style obligatory for all' (Nietzsche 1982: 46-47). In the written or oral traditions of the founding of civilizations, a lie has an ambiguous status. For example, 'You shall not give false testimony against your neighbor' (Exodus 20: 16) has an interpretable form in every sense. Beyond any interpretation of this statement, one thing is certain: the lie is not firmly condemned and it is unconditionally considered a non-value. However, in certain circumstances, it is allowed and worshiped as pia fraus. In his work 'On Lying', St. Augustine evokes the lie worthy of praise (dignum laude mendacium) in the context of analysing passages from the Bible in which lying is permitted as a context for a noble purpose (Augustine 2016: 44).

In the cultural tradition of many nations, it can be said that truth, through itself, is unattractive as opposed to lying, which can still be repulsive in itself. Most of the time, people run away from the truth. It can only be assimilated when it is surrounded by lies. Without the 'aura' of the lie, the truth has no power and no charm. 
No civilization could have been built without a certain type of lie. This is what Nietzsche calls a conventional lie. In turn, H.-G. Gadamer tried to create the hermeneutics of what he calls the 'state of a lie' (Gadamer 2001: 492) by which he understands the situation as one 'in which the sense for what is true, and for truth in general, has been lost' (Gadamer 2001: 492). Language is often perverted in such a way that instead of communicating a truth, it hides it in whole or in part. The hermeneutic reflection, according to Gadamer, is focused on this concealment 'because hermeneutics usually occur where communication and self-communication refuse to occur' (Gadamer 2001: 493). This is together with the language that we unconsciously use to take over the series of latent prejudices that any language contains. However, the conventional lie must be distinguished from prejudice. As is well known, prejudices are unconscious as opposed to conventional lies, which most people are aware of. However, they treat them as if they are truths.

When we are dealing with lies in the ordinary meaning of the term, the one who is lying is alienated from himself (Gadamer 2001: 493). This is valid for everything that is called a lie that, at least in a formal way, any rational man condemns. In the case of the conventional lie, however, no dialogue partner 'stays related only to himself', according to Gadamer. Both partners are excluded from communication in the sense that they do not actually communicate anything through the conventional lies. They also do not hide anything from one another. This paradoxical aspect is easy to understand in the case of the simplest form of conventional lie - politeness.

In this regard, here is what I. Kant says in the subchapter 'About Lie' in the 'Metaphysic of Morals': 'Can an untruth, said from simple politeness, (for example, the way too humble formula at the end of a letter) pass as a lie? Nothing can go wrong with that' (Kant 1991: 272). Conventional lies, such as the ones related to politeness according to Kant, do not mislead anyone because they are meant for all and, to a certain extent, they are useful to all as well. The conventional lie is not a premeditated untruth. It is one that is tacitly accepted by the whole of society. By some kind of convention or social contract, certain flagrant untruths are treated as if they were the deepest truths and they are worshiped accordingly. It may seem curious that the one who uses conventional lies is not sanctioned from a moral point of view, but instead the one who exposes them as lies is. The former passes as civilized, elegant, well-behaved and good-mannered while the latter passes as barbarian, unmannered and uneducated. The society rewards, not only from a moral point of view but also materially, those who maintain its conventional lies. This category includes all types of ideologues whose profession consists essentially in the propagation of conventional lies such as the religious or political.

We all live, no matter what civilization we are a part of, in the company of conventional lies that we ignore. If we are aware of them or acknowledge them, then we do not think of them as something that is morally condemnable. Some authors talk about 'a grey area of the lie' (Dietz 2017: 47) where the politeness, advertisement and other similar cultural phenomena are located and where the lie is tacitly accepted.

In 1883, M. Nordau published the work 'Die Konventionellen Lügen der Kulturmenscheit' in which he presents the main types of conventional lies found in Western civilization that are also broadly found in all civilizations. 'Banned in Russia, confiscated in Austria and included on the Vatican's Index, it achieved a succès de scandale that eventually resulted in over seventy editions and numerous translations' (Geller 1995: 133). For Nordau, as well as for F. Nietzsche from whose work he was probably inspired even though he ruthlessly 
criticized him in his work 'Entartung', the conventional lie is a false statement from a cognitive point of view. However, through a tacit rather than explicit convention, it is treated by all members of society as though it were true. Even when you have a clear awareness of its falsity, the unwritten rules of the respective civilization compel you not to question the truth value of such a statement.

All civilizations are based on what Ovid in 'Metamorphoses' called the pia fraus, or the holy lie that becomes a saviour in certain circumstances. All of the 'improvers of mankind', as Friedrich Nietzsche sarcastically calls people of national or worldwide historical significance, have made full use of pia fraus. Such great individuals who have instituted new value systems used the lie but they were forced to do so in order to change the world for the better. 'Neither Manu nor Plato, neither Confucius nor the Jewish and Christian teachers, ever doubted their right to tell lie. Nor did they doubt their possession of other right... Expressed in a formula, one might say: every means hitherto employed with intention of make mankind moral has been throughly immoral' (Nietzsche 1990: 69-70). Individuals of crucial importance, as K. Jaspers calls them, not only resorted to lying in order to 'improve' mankind, but the lie itself remained in the essence of civilization as a conventional lie. Nietzsche has often referred to the immorality of morality or to the fact that any morality is imposed by means that are condemned as immoral. The conventional lie has a special status in this perverse mechanism for the 'improvement of humanity.' It will continue to be worshipped even when the new civilization is at the peak of its power and one should not be afraid to tell the truth. However, when conventional lies are viewed with suspicion and are systematically disclosed, regardless of whether they refer to the founders of religions or states or not and whether or not they are political or matrimonial lies, the respective civilization decays and will soon collapse.

According to Nietzsche, the psychological motivation for respecting the civilization of conventional lies is 'The beast within us wants to be lied to; morality is the conventional lie (Notlüge). Without the errors that lie in the assumptions of the morality, the individual would have remained an animal' (Nietzsche 1990: 57). In other words, lying is a human phenomenon - a way too human one. 'Lies can't be avoided, so we have to learn to live with them' (Dietzsch 1998: 14). An important lesson in this regard is given by A. Schopenhauer: do not lie, but do not tell all the truths! The truth, in turn, is often told in order to conceal other untruths. For instance, in almost every confession that has entered into the history of culture, one can easily observe how much effort the 'confessor' puts in when revealing and presenting, in great detail, the minor sins which even the most unforgiving god would ignore. This is while the abominable deeds he has committed and 'forgotten' are silenced. Both in theory and in practice, lie and truth always appear together as two solid concepts. Whoever does not know or cannot lie, when the circumstances require it, is a sick man. A schizophrenic cannot lie (Baruzzi 1996: 18-19).

In the following, we will refer to some of the different types of conventional lie present in specific forms in all civilizations. A series of misunderstandings or even conflicts could be avoided if the conventional lies were taken into account in the process of intercultural communication.

\section{THE RELIGIOUS LIE}

In a few fragments from the 'The Will to Power', Nietzsche criticizes the sacred lies of religion. He states the following: 'That a lie is allowed in pursuit of holy ends is a principle which belongs to the theory of all priestcraft' (Nietzsche 1914: 120). Such a type of lie has always 
been skillfully formulated so then the priesthood has the power or to become a substitute for political power itself. 'The holy lie therefore invented... a god who punishes and rewards, who recognises and carefully observes the law-book of the priests, and who is particular about sending them into the world as his mouthpieces and plenipotentiaries' (Nietzsche 1914: 122). Therefore, the sacred religious lie is ultimately an expression of the will and power of the priesthood caste. What happens in Christianity with the conventional religious lie does not represent a particular case because it happens in other religions as well.

All Christians know, or at least intuit, the fact that their religion did not begin with Jesus as a historical person. They pretend that this is the truth. In a fragment entitled 'Pia fraus or something else, Friedrich Nietzsche reveals both religious and political duplicity which, in Germany of his era, has become an obligation of the moment for all (Nietzsche 1990: 489-490).

The sincere belief in divinity has nothing to do with lying. This occurs when belief is only mimicked. In addition, the conventional religious lie manifests itself in the sphere of the relationship of the church with society and the relationship between the individual and the church. In this sense, the Antichrist of Friedrich Nietzsche is an exercise in intellectual honesty and boldness when unmasking conventional religious lies. 'By this term I wish to express the reverence paid by men, even of the most advanced culture, to the positive, external forms of Religion, its dogmas, doctrines, observances, festivals, ceremonies, symbols, and ministers' (Nordau 1896: 56).

Examples of conventional religious lies are uncountable and they can be easily spotted in all religions and confessions around the world. In the case of Christianity, for instance, the statement that some objects have miraculous properties by the mere fact that a priest sanctifies them is a conventional lie (Nordau 1896: 60).

Another example of a religious lie is that the Holy Spirit has been involved in the election of the Pope. In reality, we are dealing only with the actions and decisions of people (Nordau 1896: 558-59).

The unmasking of conventional religious lies, regardless of their type, even today involves enormous risks because this deals with the very foundation of a religion and, implicitly, the foundation of a whole civilization is called into question.

\section{THE MATRIMONIAL LIE}

The family established by marriage is a fundamental institution in all civilizations and, regardless of its form, it has always been surrounded by a series of conventional lies. The special importance of marriage is marked by a public ceremony in all civilizations. Those who avoid such a public consecration of their marital union are often stigmatised or punished by the society in question. The tacit principle of the public consecration of marriage is that such a relationship between a man and a woman is not just a private matter. In one way or another, it concerns the fate of the whole of society and, ultimately, the fate of humanity. Future generations depend on the present and especially on the way in which marriage and the family resulting from it are understood.

Regarding Western civilization from the late 19th century onwards, Nordau, in a text dedicated to the matrimonial lie, stated the following: 'What have the lies of our civilization made out of marriage? It has become a mutual agreement in which there is no more room for love, than in the partnership contract of two capitalists entering upon some new business enterprise together' (Nordau 1896: 260). The capitalist selfishness, Nordau notes, triumphs 
even within the family where only solidarity should be present. In European civilizations, based on Christianity as a religion of love, love is missing from the family constitution. The conventional matrimonial lie consists precisely of the fact that the family acquires a certain moral sanctity, being formally ascribed to love. However, in reality, the material interest or other interests that have nothing spiritual in them prevail. What Max Nordau noticed about family more than a century ago has remained essentially valid to this day.

Marriage based on love is, in most cases, a conventional lie of civilization. Even if we ignore the important literature dedicated to love, there are still a lot of very deep scientific works about love if we think about Stendhal, Balzac, Max Scheler, Ortega y Gasset or any of the other truly exceptional and honest authors. Nordau, inspired in this regard, refers to Goethe in order to explain the essence of love. For the author of 'Faust', love is an 'elective affinity' concept that he takes from chemistry. He translates it into the enigmatic attraction between a man and a woman. 'Affinity in chemistry means that attraction between the particles of two bodies which causes them to unite and blend, thus forming a new compound completely different in almost all its properties, in colour, density, and effect upon other matter, composition, etc., from the two ingredients of which it is formed' (Nordau 1896: 264). The bodies between which there is no elective affinity do not react in any way when they are close to one another or when they are in contact. The human being as a whole, with its spirit, its soul and its body, relates to other people through the law of elective affinities. This 'chemistry' belongs to the essence of life and it will probably remain an enigma forever. Therefore, the conventional matrimonial lie consists in the affirmation that there is elective affinity where it does not actually exist.

In his essayistic style, Friedrich Nietzsche presents the matrimonial lie as follows: 'The institution of marriage stubbornly upholds the belief that love although a passion is nevertheless capable of endurance indeed that lasting lifelong love may be taken as a general rule. By means of the tenacity of a noble belief in spite of such frequent and almost customary refutations - thereby becoming a pia fraus - marriage has elevated love to a higher rank' (Nietzsche 1911: 34). Not only Western civilization, to which Nietzsche and Nordau mainly refer, but all civilizations, as they all use specific matrimonial lies.

\section{THE POLITICAL LIE}

In the modern period, individuals have talked openly and developed theories about the right to lie (Dietzsch 1998: 55). For instance, in 1780, the Prussian Science Academy launched a prize for an answer to the question on whether it is useful for the nation to be lied to. In other words, is the political factor justified or even forced to lie to the nation that it governs when the circumstances are of such nature that the lie would be for the general good? Machiavelli's answer from 'Il Principe' is well-known, which is why the problem in question became all the more complicated given that Frederick the Great of Prussia published the work 'Anti-Machiavelli'. This was where he made it clear that lying and deception are not allowed under any circumstances. Some authors have convincingly argued the thesis according to which citizens have the right to be lied to by the state if the lie was for their own good (Shibles 2000: 12). Others, for instance, Kant, advocate for the absolute exclusion of lies from politics (Kant 1979: 502).

On a political level, the conventional lie often takes the form of myths such as the founding myths of nations, the myth of the divine origin of a monarchy, the myth of aristocracy and the Arian myth to name only a few types. In the modern era, the myth is built like any other 
weapon with the precise purpose of arming the minds of compatriots and artificially arousing the exaggerated hatred against a real or imaginary adversary (Cassirer 1946: 277-296).

Parliamentary democracy is, according to Nordau, an example of a conventional political lie in the sense that between theory and reality there is an obvious contradiction. From a theoretical point of view, parliamentary democracy is about the rational legitimisation of power but, as is well known, rationality is itself strongly culturally-modelled. What is 'rational' from the perspective of one civilization is irrational from the perspective of another.

In addition to the fact that Karl Jaspers has shown that all forms of legitimacy of power are criticisable, they all use and abuse conventional lies. Parliamentary democracy, in essence, represents the power of the people exercised through a vote which results in a certain configuration of the parliament. Theoretically, the nation is sovereign. It behaves like a sovereign from another time, replacing the absolute monarch from the old times. In theory, the sovereign people have absolute power, but in practice the situation is quite different. The claim is that in a political system based on parliamentary democracy, the fact that the people are sovereign is a political lie (Nordau 1896: 162). Because most members of such a society behave as if this great lie is the absolute truth, we have to deal with a conventional lie (Nordau 1896: 163). This was as valid a century ago as it is today only in theory. In practice, selfishness and self-interest take precedence in any 'representative' of the 'sovereign people. As a general rule, in any parliament, each individual represents himself or a small group from which he tries to take advantage on all levels. Theoretically, the most valuable members of society should reach the parliament, but in reality 'parliamentarianism has one advantage; it makes it possible for those who are ambitious, to rise by utilizing their fellow-citizens' (Nordau 1896: 165).

What happens in a democracy with the truly exceptional personalities who carry the highest values? Really great people have always existed but they have no chance compared to the demagogue who represents success at all levels in a parliamentary democracy (Nordau 1896: 167-168). Truly great people in any field that they manifest not only try to gain the public's favour but they also create valuable works and take actions that change the world against the public. 'Reformers and martyr spirits sometimes appear before the multitude, but only to instruct it, to point out its faults, to tear it away from its cherished customs, not to flatter it, confirm it in its errors, and repeat in honeyed terms what it loves to listen to. Hence they are more often stoned than crowned with flowers' (Nordau 1896: 172-173).

Another conventional lie in the political field is that decisions are made by the representatives of the sovereign people following free debates in the Parliament. This is, in theory and in reality, where 'the public sessions are scenes without any real significance. Debates are carried on so as not to allow the fiction of Parliamentarianism to be dropped' (Nordau 1896: 180). Everything is pre-set so then everything that is said during the debates is completely indifferent to the result. Everything is directed. Some unscrupulous politicians decide everything with the help of a mercenary army composed of votes and speeches.

Conventional lies in a parliamentary democracy, as Nordau pointed out a century ago, are not only valid today but they have also multiplied and become much more difficult to discover. Other forms of government are also based on conventional political lies. The systems of monarchy and aristocracy also rely on conventional lies. By tradition, certain classes, such as the aristocracy with its various forms and the monarchy, are at the forefront of a national or multinational community. In general, the monarchy relies on the myth of its 
divine origin. In certain times and cultural spaces, the monarch is seen of as a descendant of the gods while in others, as in medieval Europe, they are a representative of the divinity on earth. Aristocracy relies on the conventional lie that the aristocrat, as the etymology of the word indicates, is the noblest, most distinguished and most morally pure son of the nation. From this perspective, the monarch should be on an even higher level. As is known, there has never been such a situation in the history of mankind but this conventional lie has worked in the case of all nations and in all eras. Everyone bows respectfully, even if in a directed and calculated manner, in front of the one designated as Your Highness, Majesty or Monsignor. For a long time, the monarchy is reminded of the sacred origin of its power by writing on all of the documents issued by it a formula of the type 'By the grace of God' (Nordau 1896: 72).

The conventional political lies of civilizations have a certain dynamic. They remain valid so long as the power that is legitimized by them resists criticism.

\section{CONCLUSIONS}

Conventional lies are inherent to any civilization and they represent the most sensitive points in the process of intercultural communication. Over large time intervals, they are exposed and eliminated but they are immediately replaced by others, as is the case with prejudice. Knowing the conventional lies of each civilization nowadays represents an important aspect of intercultural competence.

Received 24 March 2020 Accepted 1 June 2020

\section{References}

1. Augustine, S. 2016. On Lying. Bucharest: Humanitas Publishing House.

2. Baruzzi, A. 1996. Philosophie der Lüge. Darmstadt: Wissenschaftliche Buchgesellschaft.

3. Cassirer, E. 1946. The Myth of the State. New Haven: Yale University Press.

4. Dietz, S. 2017. Die Kunst des Lügens. Stuttgart: Reclam Verlag.

5. Dietz, S. 1998. Kleine Kulturgeschichte der Lüge. Stuttgart: Reclam Verlag.

6. Gadamer, H. G. 2001. Truth and Method. Bucharest: Teora Publishing House.

7. Geller, J. 1995. 'The Conventional Lies and Paradoxes of Jewish Assimilation: Max Nordau's Pre-Zionist Answer to the Jewish Question', Jewish Social Studies 1(3): 129-160.

8. Kant, I. 1991. Metaphysic of Morals. Bucharest: Scientific Publishing House.

9. Kant, I. 1979. 'Über ein vermeintes Recht aus Menschenliebe zu lügen', in Von den Träumen der Vernunft. Kleine Schriften zur Kunst, Philosophie, Geschichte und Politik. Leipzig and Weimar: Gustav Kiepenheuer Verlag.

10. Nietzsche, F. 1982. 'On Truth and Lie in an Extra-Moral Sense', in The Portable Nietzsche. New York: Penguin Books.

11. Nietzsche, F. 1990. Twilight of the Idols. London: Penguin Books.

12. Nietzsche, F. 1990. 'Menschliches, Allzumenschliches', in Das Hauptwerk. Band I. München: Nymphenburger Verlag.

13. Nietzsche, F. 1914. The Will to Power. An Attempted Transvaluation of all Values. Edinburgh and London: T. N. Foulis. Available at: https://www.gutenberg.org/files/52914/52914-h/52914-h.htm

14. Nietzsche, F. 1911. The Dawn of Day. New York: The MacMillan Company. Available at: https://www. gutenberg.org/files/39955/39955-h/39955-h.html

15. Nordau, M. 1896. The Conventional Lies of Our Civilization. London: William Heinemann. Available at: https://ia801605.us.archive.org/3/items/in.ernet.dli.2015.35464/2015.35464.Conventional-Lies-OfOur-Civilization_text.pdf

16. Penslar, D. J. 1996. 'From "Conventional Lies" to Conventional Myths: Max Nordau's Approach to Zionism, History of European Ideas 22(3): 217-226.

17. Shibles, W. 2000. Lügen und lügen lassen. Eine kritische Analyse des Lügens. Mainz: Lermann Verlag. 
NICOLAE RÂMBU

\section{Iprastas melas - beveik pamiršta sąvoka}

\section{Santrauka}

Iprasto melo sąvoką, kurią pirmasis apibrèžè Friedrichas Nietzsche, reikètų vartoti kultūros mokslų diskurse. Daugybė juo žymimų reiškinių paprastai yra klaidingai klasifikuojami priskiriant stereotipų arba vieno iš prietarų kategorijai. Šiame straipsnyje ginama tezè, kad ịprastas melas reiškia specifinį kultūros kaip „proto programinès įrangos" elementą.

Raktažodžiai: tarpkultūrinè komunikacija, Friedrichas Nietzsche, moralės nemoralumas 